\title{
Organ and Tissue Procurement Facility
}

National Cancer Institute

\section{Source}

National Cancer Institute. Organ and Tissue Procurement Facility. NCI Thesaurus. Code C133324.

An organ procurement organization that also recovers tissues. 